\title{
ANALISIS ALIH FUNGSI LAHAN PERTANIAN DI KABUPATEN KEDIRI
}

\author{
Syarif Imam Hidayat ${ }^{* 1}$ dan Lisanul Latifatul Rofiqoh ${ }^{1}$ \\ ${ }^{1}$ Fakultas Pertanian UPN "Veteran" Jawa Timur \\ e-mail: *1Syarifimamhidayat@yahoo.com
}

\begin{abstract}
Kediri Regency as one of the Food Reserves in East Java experienced a decrease in the area of agricultural land due to land conversion in the period 2005-2016. Transfer of agricultural land functions is a serious threat to the sustainability and self-sufficiency of food, especially for the main food commodities namely rice, corn and soybeans. Transfer of function of agricultural land can cause the availability of agricultural land for sustainable food decreases. This study aims to: analyze the potential factors that affect the conversion of agricultural land, and analyze the extent of the influence of land conversion on the main food commodities (rice, corn, soybeans). The study uses secondary data from several related agencies, while determining the location is determined purposively. The data collected is then processed and analyzed using multiple linear regression. The results showed that the factors that had a significant influence on the conversion of agricultural land were population, industry and GRDP, while productivity (rice, corn, soybeans) and FTT had no significant effect.
\end{abstract}

Keywords: Change of function of agricultural land, main food production

\section{PENDAHULUAN}

Latar belakang dari alih fungsi lahan pertanian menjadi non pertanian merupakan konsekuensi dari perkembangan wilayah juga akibat dari pertumbuhan penduduk, infrastruktur maupun industri. Pertumbuhan penduduk yang dinamis pada saat ini menyebabkan keberadaan lahan pertanian terancam untuk kebutuhan lain seperti perumahan, jalan, industri dan sebagainya. Hal inilah yang menyebabkan ketersediaan lahan pertanian menjadi berkurang (Maleha dan Susanto, 2006).

Alih fungsi lahan pertanian merupakan salah satu permasalahan yang sedang dihadapi dalam bidang pertanian di Indonesia. Satu hal yang mungkin tidak menjadi bahan pertimbangan dalam melakukan alih fungsi lahan adalah dampak yang ditimbulkan dari alih fungsi lahan tersebut. Penurunan produksi pangan yang diakibatkan oleh alih fungsi lahan lebih bersifat permanen dan sulit untuk diperbaiki. Bagi sektor pertanian, lahan merupakan faktor produksi utama dan tak tergantikan (Maleha dan Susanto, 2006).

Indonesia sebagai negara agraris masih mengalami kesulitan dalam mengendalikan alih fungsi lahan karena jumlah penduduk dan pembangunan di segala bidang yang terus meningkat menyebabkan semakin besarnya kebutuhan ruang yang berdampak pada semakin tingginya alih fungsi lahan pertanian. Apabila fenomena alih fungsi lahan pertanian terus meningkat tanpa pengendalian dan pengawasan yang tegas maka dapat mengganggu stabilitas kemandirian, kedaulatan, dan ketahanan pangan baik lokal maupun nasional. (Irawan, 2005). 
Ketahanan pangan (food security) sangat erat kaitannya dengan persediaan pangan. Pangan merupakan komoditas penting dan strategis, karena posisinya sebagai kebutuhan dasar yang harus dipenuhi. Produksi pangan selama ini di dominasi dari hasil tanaman padi yang ditanaman di lahan sawah subur, baik (sawah irigasi dan tadah hujan). Dengan demikian bila konversi lahan terus meningkat maka dapat mengganggu produksi dan ketersediaan pangan. Pertumbuhan penduduk, perkembangan sektor industri, dan perumahan menyebabkan peningkatan kebutuhan akan lahan pertanian. (Irawan, 2003).

Mengingat dampak yang ditimbulkan oleh adanya konversi lahan yang begitu luas, maka diperlukan upaya pengendalian yang dapat mengontrol laju alih fungsi lahan pertanian menjadi lahan non pertanian dengan menjadikan aspek daya dukung lingkungan dan ketersediaan lahan sebagai salah satu pertimbangan. paya pengendalian alih fungsi lahan pertanian dan perlindungan terhadap lahan pertanian produktif perlu didukung oleh suatu peraturan perundang-undangan (Laksmana, 2015) . Konversi lahan mempunyai beberapa peraturan yang tercantum di dalam undang-undang dasar Negara Indonesia salah satunya yaitu; UU RI No. 41 Tahun 2009 tentang Perlindungan Lahan Pertanian Pangan Berkelanjutan (PLPPB) dalam rangka mengendalikan alih fungsi lahan pertanian dan untuk menjaga ketahanan pangan dalam rangka swasembada pangan.

Secara nasional, petani tanaman pangan menjadi subyek yang penting dalam ketersediaan pangan. Hal ini karena pemerintah mencanangkan kemandirian pangan melalui swasembada pangan. Namun meningkatnya alih fungsi lahan pertanian produktif akan berdampak pada ketersediaan pangan secara wilayah dan secara nasional (Yunastiti, Sutomo, \& Nurul Istiqomah, 2015). Dengan demikian perlu diteliti terkait semakin meningkatnya alih fungsi lahan pertanian di Kabupaten kediri dampaknya terhadap produksi pangan utama yaitu padi, jagung dan kedelai.

Tujuan dalam penelitian ini adalah: menganalisis faktor-faktor potensial yang mempengaruhi alih fungsi lahan pertanian, dan menganalisis sejauh mana pengaruh alih fungsi lahan terhadap komoditas utama pangan (padi, jagung, kedelai).

\section{METODE PENELITIAN}

\section{Lokasi dan Waktu Penelitian}

Lokasi penelitian ini dipilih secara purposive method di Kabupaten Kediri, dengan pertimbangan bahwa di daerah tersebut setiap tahun rata-rata terjadi alih fungsi lahan pertanian $\pm 150 \mathrm{Ha}$ /tahun. Tingginya tingkat alih fungsi lahan menjadi perumahan maupun yang lainnya seiring dengan pertumbuhan penduduk yang cukup pesat, dan hal ini mengindikasikan terjadinya alih fungsi lahan pertanian ke non pertanian. Waktu Penelitian dilaksanakan pada bulan Januari hingga Mei 2019.

\section{Teknik Pengumpulan Data}

penelitian ini metode pengumpulan data dilakukan dengan menggunakan data sekunder. Survei data sekunder terdiri atas survei instansional untuk memperoleh data sekunder yang memiliki relevansi dengan pembahasan dalam penelitian serta survei literatur. data sekunder diperoleh dari berbagai lembaga atau instansi seperti BPS Kabupaten Kediri, Dinas Pertanian dan Perkebunan Kabupaten Kediri, Dinas Perindustrian Kabupaten Kediri, laporan-laporan, publikasi dan pustaka lainnya. 


\section{Analisis Data}

Data dianalisis secara kuantitatif dengan menggunakan analisis sebagai berikut :

Persamaan model regresi linear berganda untuk mengetahui faktor-faktor yang mempengaruhi alih fungsi lahan pertanian adalah sebagai berikut:

$$
\operatorname{LnY}=\alpha+\beta 1 \operatorname{Ln} X 1+\beta 2 \operatorname{Ln} X 2+\beta 3 \operatorname{LnX} 3+\beta 4 \operatorname{LnX} 4+\beta 5 \operatorname{LnX} 5+\varepsilon
$$

dimana :

$\mathrm{Y}=$ Luas Alih Fungsi Lahan Pertanian (Ha)

$\alpha=$ intersep/konstanta

$\mathrm{X} 1$ = Jumlah Penduduk (jiwa)

$\mathrm{X} 2$ = Jumlah Industri (unit)

X3 = PDRB non-pertanian (Rp juta)

$\mathrm{X} 4=$ Produktivitas (padi, jagung dan kedelai) (ton/ha)

X5 = Nilai Tukar Petani $(\%)$

$\beta i=$ Koefisien regresi

$\varepsilon=$ Eror Term

Untuk mengetahui seberapa jauh pengaruh faktor-faktor yang telah ditentukan dalam persamaan akan mempengaruhi alih fungsi lahan, dilakukan pengujian ketelitian dan pengujian kemampuan model regresi. Dalam penelitian ini, pengujian model regresi terdiri dari tiga pengujian, yaitu uji koefisien determinasi (R2), uji koefisien regresi parsial (t), dan uji koefisien regresi menyeluruh $(\mathrm{F})$.

\section{HASIL DAN PEMBAHASAN}

\section{Faktor-faktor Yang Mempengaruhi Luas Alih Fungsi Lahan Pertanian di Kabupaten Kediri}

Analisis dalam penentuan faktor-faktor yang di duga mempengaruhi alih fungsi lahan pertanian di tingkat wilayah digunakan analisis regresi linier berganda. Analisis ini bertujuan untuk menganalisis pengaruh variabel jumlah penduduk, jumlah industri, PDRB non pertanian, produktivitas (padi, jagung dan kedelai) dan NTP terhadap Alih Fungsi Lahan pertanian di Kabupaten Kediri. Berdasarkan pengujian, persamaan regresi dapat dilihat dalam tabel di bawah ini:

Coefficients $^{\mathbf{a}}$

\begin{tabular}{|c|c|c|c|c|c|c|}
\hline \multirow{2}{*}{\multicolumn{2}{|c|}{ Model }} & \multicolumn{2}{|c|}{$\begin{array}{c}\text { Unstandardized } \\
\text { Coefficients }\end{array}$} & \multirow{2}{*}{$\begin{array}{c}\begin{array}{c}\text { Standardized } \\
\text { Coefficients }\end{array} \\
\text { Beta }\end{array}$} & \multirow[b]{2}{*}{$\mathrm{T}$} & \multirow[b]{2}{*}{ Sig. } \\
\hline & & B & Std. Error & & & \\
\hline \multirow[t]{6}{*}{1} & (Constant) & -485.816 & 300.820 & & -29.701 & .000 \\
\hline & jumlah penduduk & .002 & .001 & .646 & 2.675 & .023 \\
\hline & jumlah industri & .558 & .181 & .699 & 3.088 & .011 \\
\hline & $\begin{array}{l}\text { PDRB non } \\
\text { pertanian }\end{array}$ & 4.604 & .000 & .589 & 2.302 & .044 \\
\hline & $\begin{array}{l}\text { Produktivitas (padi, } \\
\text { jagung, kedelai) }\end{array}$ & -30.048 & 33.137 & .276 & -.907 & .386 \\
\hline & NTP & -2.804 & 1.322 & .557 & -2.122 & .060 \\
\hline
\end{tabular}


Coefficients $^{\mathrm{a}}$

\begin{tabular}{|c|c|c|c|c|c|c|}
\hline \multirow{2}{*}{\multicolumn{2}{|c|}{ Model }} & \multicolumn{2}{|c|}{$\begin{array}{l}\text { Unstandardized } \\
\text { Coefficients }\end{array}$} & \multirow{2}{*}{$\begin{array}{c}\begin{array}{c}\text { Standardized } \\
\text { Coefficients }\end{array} \\
\text { Beta }\end{array}$} & \multirow[b]{2}{*}{$\mathrm{T}$} & \multirow[b]{2}{*}{ Sig. } \\
\hline & & B & Std. Error & & & \\
\hline \multirow[t]{6}{*}{1} & (Constant) & -485.816 & 300.820 & & -29.701 & .000 \\
\hline & jumlah penduduk & .002 & .001 & .646 & 2.675 & .023 \\
\hline & jumlah industri & .558 & .181 & .699 & 3.088 & .011 \\
\hline & $\begin{array}{l}\text { PDRB non } \\
\text { pertanian }\end{array}$ & 4.604 & .000 & .589 & 2.302 & .044 \\
\hline & $\begin{array}{l}\text { Produktivitas (padi, } \\
\text { jagung, kedelai) }\end{array}$ & -30.048 & 33.137 & .276 & -.907 & .386 \\
\hline & NTP & -2.804 & 1.322 & .557 & -2.122 & .060 \\
\hline
\end{tabular}

Dependent variable: luas alih fungsi

lahan $(\mathrm{Y})$

Berdasarkan Tabel di atas, diperoleh model persamaan regresi :

$\mathrm{Y}=\mathrm{a}+\beta 1 \mathrm{X} 1+\beta 2 \mathrm{X} 2+\beta 3 \mathrm{X} 3+\beta 4 \mathrm{X} 4+\beta 5 \mathrm{X} 5+\mathrm{e}$

$\mathrm{Y}=-485.816+0.002 \mathrm{X} 1+0.558 \mathrm{X} 2+4.604 \mathrm{X} 3-30.048 \mathrm{X} 4-2.804 \mathrm{X} 5+\mathrm{e}$

Dimana :

$\mathrm{Y}=$ Luas Alih Fungsi Lahan Sawah (Ha)

$\mathrm{X} 1$ = Jumlah penduduk (jiwa)

$\mathrm{X} 2$ = Jumlah industri (unit)

X3 = PDRB Non pertanian (Juta)

$\mathrm{X} 4$ = Produktivitas (padi,jagung, kedelai) (ton/ha)

$\mathrm{X} 5=\mathrm{NTP}(\%)$

$\mathrm{a}=$ Intersep/Konstanta

Jumlah penduduk berpengaruh positif terhadap luas alih fungsi lahan, apabila jumlah penduduk meningkat sebesar 100 jiwa per tahun, maka akan terjadi peningkatan luas alih fungsi lahan pertanian sebesar 0,002 Ha. Jumlah industri berpengaruh positif terhadap luas alih fungsi lahan, apabila jumlah indah industri meningkat sebesar 1 unit per tahun, maka terjadi peningkatan luas alih fungsi lahan pertanian sebesar 0,558 Ha. PDRB non pertanian berpengaruh positif terhadap luas alih fungsi lahan pertanian, apabila nilai PDRB non pertanian meningkat sebesar satu juta rupiah setiap tahunnya, maka akan terjadi peningkatan luas alih fungsi lahan pertanian sebesar 4,604 Ha. Sedangkan produktivitas (padi,jagung dan kedelai) dan NTP berpengaruh negatif terhadap luas alih fungsi lahan pertanian. Apabila produktivitas (padi, jagung dan kedelai) meningkat sebesar 1 ton/ha setiap tahunnya, maka terjadi penurunan luas alih fungsi lahan pertanian sebesar 30,048 Ha dan apabila indeks pertumbuhan NTP meningkat sebesar $1 \%$ setiap tahunnya, maka akan terjadi penurunan alih fungsi lahan pertanian sebesar 2,804 Ha. 


\section{Uji Hipotesis}

\section{Koefisien Determinasi ( R2 )}

Koefisien determinasi (R2) dilakukan untuk melihat adanya hubungan yang sempurna atau tidak, yang ditujukan pada apakah perubahan variabel bebas (jumlah penduduk, jumlah industri, PDRB non pertanian, produktivitas dan NTP) akan diikuti oleh variabel terikat (alih fungsi lahan). Koefisien determinasi (R2) pada intinya mengukur seberapa jauh kemampuan model dalam menerangkan variasi variabel bebas. Nilai koefisien determinasi adalah diantara nol dan satu. Berikut hasil Uji Koefisien Determinasi.

Model Summary

\begin{tabular}{|l|r|r|r|r|}
\hline Model & $\mathrm{R}$ & $\mathrm{R}$ Square & \multicolumn{1}{|c|}{$\begin{array}{c}\text { Adjusted R } \\
\text { Square }\end{array}$} & $\begin{array}{l}\text { Std. Error of the } \\
\text { Estimate }\end{array}$ \\
\hline 1 & $.993^{\mathrm{a}}$ & .976 & .965 & 9.909 \\
\hline
\end{tabular}

a. Predictors: (Constant), NTP, produktivitas (padi,jagung dan kedelai), PDRB Non pertanian, jumlah industri, jumlah penduduk

Nugroho (2005) mengatakan bahwa nilai koefisien determinasi yang baik yaitu jika nilainya di atas 0.5 persen (50\%), karena nilai koefisien determinasi berkisar antara 0 hingga 1. Berdasarkan hasil pengujian dapat di lihat pada Tabel di atas, diperoleh nilai R-square (R2) yaitu sebesar 0,976 (97,6 \%) yang menunjukkan bahwa keragaman dari variabel dependen yaitu alih fungsi lahan pertanian dapat diterangkan oleh variabel independennya yaitu: jumlah penduduk, jumlah industri, PDRB Non pertanian, produktivitas (padi, jagung dan kedelai) dan NTP sebesar 97,6\%. Artinya variabel independen memiliki pengaruh sempurna terhadap alih fungsi lahan pertanian sebesar $97,6 \%$ sedangkan sisanya diterangkan oleh variabel independen lain yang tidak ada di dalam model, misalnya keputusan petani sendiri, dan proporsi pendapatan di sektor pertanian.

\section{Uji F}

Uji $\mathrm{F}$ ini digunakan untuk menguji apakah independen $(\mathrm{X})$ berpengaruh secara simultan (bersama-sama) terhadap variabel dependen $(\mathrm{Y})$, kriteria pengujian uji $\mathrm{F}$ dalam penelitian ini adalah dengan melihat sig $\mathrm{F}$. Apabila nilai sig $\mathrm{F}<0,05$ maka Ho ditolak $\mathrm{H}_{1}$ diterima, artinya diduga ada pengaruh antara variabel $(\mathrm{X})$ dan variabel $(\mathrm{Y})$.

ANOVA $^{\mathrm{b}}$

\begin{tabular}{|ll|r|r|r|r|r|}
\hline Model & & Sum of Squares & Df & Mean Square & F & \multicolumn{1}{c|}{ Sig. } \\
\hline 1 & Regression & 43041.174 & 5 & 8608.235 & 87.679 & $.000^{\mathrm{a}}$ \\
& Residual & 589.076 & 6 & 98.179 & & \\
& Total & 43630.250 & 11 & & & \\
\end{tabular}

a. Predictors: (Constant), NTP, produktivitas (padi, jagung dan kedelai), PDRB Non pertanian, jumlah industri, jumlah penduduk

b. Dependent Variable: Alih fungsi lahan

Hasil perhitungan menunjukkan bahwa nilai signifikan $F$ sebesar 0,000. Karena nilai probabilitasnya $0,000<0,05$ maka model regresi dapat dipakai untuk memprediksi alih fungsi lahan (Y), yang berarti variabel $\mathrm{X}_{1}, \mathrm{X}_{2}, \mathrm{X}_{3}, \mathrm{X}_{4}, \mathrm{X}_{5}$ secara simultan (bersama-sama) berpengaruh terhadap variabel alih fungsi lahan $(\mathrm{Y})$. 


\section{Uji T}

Hasil analisis regresi linear berganda terhadap faktor penentu luas alih fungsi lahan pertanian menunjukkan variabel jumlah penduduk, jumlah industri dan PDRB non pertanian adalah signifikan berpengaruh terhadap luas alih fungsi lahan pertanian, sedangkan produktivitas padi, jagung, dan kedelai; serta NTP tidak signifikan. Hasil persamaan dapat dilihat dalam Tabel Hasil Analisis Regresi Linier Berganda diatas.

Variabel jumlah penduduk berpengaruh positif dan nyata terhadap alih fungsi lahan pertanian. Artinya semakin tinggi jumlah penduduk di Kabupaten Kediri maka akan terjadi peningkatan alih fungsi lahan pertanian menjadi non pertanian. Hal ini karena peningkatan laju pertambahan penduduk membutuhkan lahan sebagai tempat tinggal/perumahan/pemukiman juga semakin meningkat. Luas lahan yang tetap sementara kebutuhan akan lahan yang terus meningkat dapat menyebabkan terjadinya alih fungsi lahan pertanian ke non pertanian terutama lahan sawah. Menurut Winoto (2005) faktor-faktor yang mendorong terjadinya alih fungsi lahan pertanian menjadi non-pertanian yaitu salah satunya faktor kependudukan. Pesatnya peningkatan jumlah penduduk telah meningkatkan permintaan tanah. Selain itu, peningkatan taraf hidup masyarakat juga turut berperan menciptakan tambahan permintaan lahan.

Variabel jumlah industri berpengaruh positif dan berpengaruh nyata terhadap alih fungsi lahan, hal ini berarti semakin tinggi jumlah industri di Kabupaten Kediri maka akan terjadi peningkatan alih fungsi lahan pertanian ke non pertanian. peningkatan industri membutuhkan lahan lebih besar sehingga menyebabkan terjadinya penurunan luas lahan dari pertanian menjadi kebutuhan non pertanian. Berdasarkan Data dari Dinas Perindustrian Kabupaten Kediri dalam kurun Tahun 2015-2016 menunjukkan bahwa jumlah industri di Kabupaten Kediri terus mengalami peningkatan. Menurut Irawan (2005) ada dua hal yang mempengaruhi alih fungsi lahan . Pertama, sejalan dengan pembangunan kawasan perumahan atau industri di suatu lokasi alih fungsi lahan, maka aksesibilitas di lokasi tersebut menjadi semakin kondusif untuk pengembangan industri dan pemukiman yang akhirnya mendorong meningkatnya permintaan lahan oleh investor.

Variabel PDRB Non pertanian/industri menunjukkan pengaruh positif dan signifikan terhadap variabel dependen alih fungsi lahan (Y). PDRB merupakan indikator pertumbuhan ekonomi suatu daerah. Jadi dapat disimpulkan bahwa semakin besar nilai PDRB Non pertanian di Kabupaten Kediri maka semakin terjadi peningkatan luas alih fungsi lahan pertanian. Hal ini karena kebutuhan akan sektor manufaktur/industri pasti membutuhkan lahan untuk memperluas kebutuhan bisnisnya, hal ini akan meningkatkan permintaan lahan, sehingga terjadi alih fungsi lahan dari pertanian menjadi non pertanian. Hal ini sesuai dengan penelitian yang dilakukan oleh Mustofa (2011), bahwa faktor-faktor yang mempengaruhi alih fungsi lahan pertanian di Kabupaten Demak yaitu faktor PDRB Non pertanian, selain faktor jumlah penduduk dan jumlah industri.

Variabel produktivitas (padi, jagung dan kedelai) berpengaruh tidak signifikansi terhadap luas alih fungsi lahan. Maka dapat disimpulkan bahwa seberapa pun tinggi produktivitas (padi, jagung dan kedelai) yang diperoleh petani di Kabupaten Kediri maka tidak berpengaruh nyata secara individu terhadap alih fungsi lahan pertanian di Kabupaten Kediri. Jadi dapat diinterpretasikan bahwa semakin tinggi tingkat produktivitas (padi, jagung dan kedelai) maka keputusan petani untuk melakukan alih fungsi lahan akan semakin rendah. Hal tersebut disebabkan karena semakin tinggi tingkat produktivitas yang dihasilkan, maka pendapatan yang diperoleh dari usahatani juga akan semakin tinggi, sehingga petani akan 
cenderung mempertahankan lahannya. Karena petani beranggapan bahwa lahan pertanian memiliki value yang tinggi.

Variabel NTP berpengaruh tidak signifikansi terhadap luas alih fungsi lahan, dapat disimpulkan bahwa seberapapun tinggi NTP yang diperoleh petani di Kabupaten Kediri maka tidak berpengaruh nyata secara individu terhadap alih fungsi lahan pertanian di Kabupaten Kediri. Hal ini dikarenakan semakin tinggi NTP yang diperoleh di Kabupaten Kediri maka relatif semakin sejahtera tingkat kehidupan petani yang akan membawa dampak yang baik untuk pertumbuhan ekonomi. Dengan meningkatnya nilai tukar petani akan memberikan peluang pada sektor pertanian menjadi sektor unggul dalam pembangunan. Sehingga alih fungsi lahan menjadi menurun.

\section{Dampak Luas Alih Fungsi Lahan Pertanian terhadap Produksi Pangan Utama (Padi, Jagung dan Kedelai) di Kabupaten Kediri}

Analisis regresi linear sederhana ini di maksudkan untuk mengetahui seberapa besar tingkat pengaruh antara luas alih fungsi lahan dengan perkembangan produksi pangan utama (padi, jagung dan kedelai). Untuk itu penulis sajikan hasil uji regresi linear sederhana sebagai berikut :

Coefficients $^{\mathrm{a}}$

\begin{tabular}{|c|c|c|c|c|c|}
\hline \multirow[b]{2}{*}{ Model } & \multicolumn{2}{|c|}{$\begin{array}{l}\text { Unstandardized } \\
\text { Coefficients }\end{array}$} & \multirow{2}{*}{\begin{tabular}{|c|}
$\begin{array}{c}\text { Standardized } \\
\text { Coefficients }\end{array}$ \\
Beta
\end{tabular}} & \multirow[b]{2}{*}{$\mathrm{T}$} & \multirow[b]{2}{*}{ Sig. } \\
\hline & B & Std. Error & & & \\
\hline $1 \quad$ (Constant) & 25342.536 & 9.045 & & 8.425 & .000 \\
\hline $\begin{array}{l}\text { Luas alih fungsi } \\
\text { lahan sawah }\end{array}$ & -1327.341 & .136 & -.620 & -2.499 & .032 \\
\hline
\end{tabular}

a. Dependent Variable: produksi padi

Berdasarkan hasil perhitungan diatas menunjukkan bahwa variabel luas alih fungsi lahan (X) memiliki nilai t hitung sebesar 2.499 dan nilai signifikan sebesar 0,032. Ketentuan pengambilan keputusan hipotesis diterima atau ditolak didasarkan pada besarnya nilai signifikansi. Jika signifikansi lebih kecil atau sama dengan $0,05(\leq 0,05)$ maka hipotesis H1 diterima. Hasil nilai sig. variabel luas alih fungsi lahan sawah $(X)$ yaitu sebesar 0,032<0,05 artinya variabel luas alih fungsi lahan memiliki pengaruh yang signifikan terhadap produksi padi (Y). Maka dapat disimpulkan bahwa hipotesis (H1) diterima.

Hal ini terbukti bahwa produksi padi selama kurun waktu 12 tahun yaitu tahun 20052016 mengalami penurunan, selain itu karena pada musim padi tiba masyarakat di Kabupaten Kediri secara keseluruhan rata-rata menanam padi semua, jika luas alih fungsi lahan meningkat maka secara otomatis produksi padi akan mengalami penurunan. Selain itu karena luas areal sawah yang menanam padi lebih besar dari komoditas yang lain. Sehingga jika luas alih fungsi lahan semakin meningkat setiap tahun, maka mengindikasikan terjadi penurunan produksi padi. Oleh karena itu luas alih fungsi lahan yang semakin berkurang berpengaruh signifikan terhadap produksi padi di Kabupaten Kediri. 
Coefficients $^{\mathrm{a}}$

\begin{tabular}{|c|r|r|r|r|r|}
\hline \multirow{2}{*}{ Model } & \multicolumn{2}{|c|}{$\begin{array}{c}\text { Unstandardized } \\
\text { Coefficients }\end{array}$} & $\begin{array}{c}\text { Standardized } \\
\text { Coefficients }\end{array}$ & & \\
\cline { 2 - 5 } & \multicolumn{1}{|c|}{$\mathrm{B}$} & Std. Error & \multicolumn{1}{c|}{ Beta } & \multicolumn{1}{c|}{ T } & \multicolumn{1}{c|}{ Sig. } \\
\hline $1 \quad \begin{array}{c}\text { (Constant) } \\
\quad \begin{array}{l}\text { Luas alih fungsi } \\
\text { lahan sawah }\end{array}\end{array}$ & 25269.270 & 45816.189 & & 5.515 & .000 \\
\hline
\end{tabular}

a. Dependent Variable: produksi jagung

Berdasarkan hasil perhitungan menunjukkan bahwa variabel luas alih fungsi lahan (X) memiliki nilai $\mathrm{t}$ hitung sebesar 2.239 dan nilai signifikan sebesar 0,062. Ketentuan pengambilan keputusan hipotesis diterima atau ditolak didasarkan pada besarnya nilai signifikansi. Jika signifikansi lebih kecil atau sama dengan $0,05(\leq 0,05)$ maka hipotesis $\mathrm{H}_{1}$ diterima. Hasil nilai sig. variabel luas alih fungsi lahan sawah (X) yaitu sebesar 0,062 <0,05 artinya variabel luas alih fungsi lahan tidak memiliki pengaruh yang signifikan terhadap produksi jagung (Y). Maka dapat disimpulkan bahwa hipotesis (Ho) diterima.

Berdasarkan data di BPS Kabupaten Kediri menunjukkan bahwa produksi jagung dalam kurun waktu 12 tahun terakhir yaitu 2005-2016 cenderung stabil, tidak mengalami penurunan. Selain itu karena sebagian masyarakat di Kabupaten Kediri setelah musim padi berakhir, tidak secara keseluruhan menanam jagung, ada yang menanam tanaman holtikultura maupun yang lainnya. Oleh karena itu luas alih fungsi lahan sawah tidak berpengaruh signifikan terhadap produksi jagung di Kabupaten Kediri. Hal ini terjadi selama kurun waktu 2005-2016, tidak menutup kemungkinan bahwa semakin meningkatnya luas alih fungsi lahan di Kabupaten Kediri dapat berpengaruh terhadap produksi jagung dalam beberapa tahun ke depan.

Coefficients $^{\mathrm{a}}$

\begin{tabular}{|c|c|c|c|c|c|}
\hline \multirow[b]{2}{*}{ Model } & \multicolumn{2}{|c|}{$\begin{array}{c}\text { Unstandardized } \\
\text { Coefficients }\end{array}$} & \multirow{2}{*}{\begin{tabular}{|c|}
$\begin{array}{c}\text { Standardized } \\
\text { Coefficients }\end{array}$ \\
Beta \\
\end{tabular}} & \multirow[b]{2}{*}{$\mathrm{T}$} & \multirow[b]{2}{*}{ Sig. } \\
\hline & B & Std. Error & & & \\
\hline $1 \quad$ (Constant) & 141.523 & 251.572 & & -.563 & .000 \\
\hline $\begin{array}{l}\text { Luas alih fungsi } \\
\text { lahan sawah }\end{array}$ & 6.035 & 2.973 & .540 & 2.030 & .070 \\
\hline
\end{tabular}

a. Dependent Variable: produksi kedelai

Berdasarkan hasil perhitungan menunjukkan bahwa variabel luas alih fungsi lahan (X) memiliki nilai $\mathrm{t}$ hitung sebesar 2.030 dan nilai signifikan sebesar 0,070. Ketentuan pengambilan keputusan hipotesis diterima atau ditolak didasarkan pada besarnya nilai signifikansi. Jika signifikansi lebih kecil atau sama dengan $0,05(\leq 0,05)$ maka hipotesis $\mathrm{H}_{1}$ diterima. Hasil nilai sig. variabel luas alih fungsi lahan sawah (X) yaitu sebesar 0,070<0,05 
artinya variabel luas alih fungsi lahan tidak memiliki pengaruh yang signifikan terhadap produksi kedelai (Y). Maka dapat disimpulkan bahwa hipotesis (Ho) diterima.

Berdasarkan data di BPS Kabupaten Kediri menunjukkan bahwa produksi Kedelai dalam kurun waktu 12 tahun terakhir yaitu 2005-2016 cenderung stabil, bahkan mengalami peningkatan. Selain itu karena sebagian masyarakat di Kabupaten Kediri setelah musim padi berakhir, tidak secara keseluruhan menanam kedelai, ada yang menanam tanaman holtikultura maupun yang lainnya. Oleh karena itu luas alih fungsi lahan sawah tidak berpengaruh signifikan terhadap produksi kedelai di Kabupaten Kediri. Hal ini terjadi selama kurun waktu 2005-2016, tidak menutup kemungkinan semakin meningkatnya luas alih fungsi lahan di Kabupaten Kediri dapat berpengaruh terhadap produksi kedelai dalam beberapa tahun kedepan.

\section{KESIMPULAN}

1. Jumlah penduduk, jumlah industri dan PDRB non pertanian memiliki pengaruh positif dan signifikan terhadap alih fungsi lahan pertanian di Kabupaten Kediri, sedangkan produktivitas (padi, jagung dan kedelai) dan NTP memiliki pengaruh negatif serta tidak signifikan terhadap luas alih fungsi lahan pertanian di Kabupaten Kediri periode Tahun 2005-2016.

2. Dampak luas alih fungsi lahan pertanian terhadap produksi pangan utama (padi, jagung dan kedelai) yaitu: dari hasil regresi linear sederhana menunjukkan bahwa luas alih fungsi lahan berpengaruh signifikan terhadap produksi padi, sedangkan luas alih fungsi lahan pertanian tidak berpengaruh signifikan terhadap produksi jagung dan produksi kedelai di Kabupaten Kediri periode Tahun 2005-2016.

\section{DAFTAR PUSTAKA}

Badan Pusat Statistik. Kabupaten Kediri Dalam Angka Tahun 2005-2016. BPS.Kabupaten Kediri. Kediri

Maleha dan Adi Susanto. 2006. Kajian Konsep Ketahanan Pangan. Jurnal Protein Vol XIII (2).

Mustopa, Zaenil. 2011. "Analisis Faktor-Faktor Yang Mempengaruhi Alih Fungsi Lahan Pertanian di Kabupaten Demak". Skripsi. Fakultas Ekonomi. Universitas Diponegoro. Semarang.

Irawan, Bambang. 2003. Konversi Lahan Sawah di Jawa dan Dampaknya Terhadap Produksi Padi. Ekonomi Padi dan Beras Indonesia : 295- 325. Badan Litbang Pertanian

Irawan, Bambang. 2005. Konversi Lahan Sawah: Potensi Dampak, Pola Pemanfaatannya dan Faktor Determinan. Pusat Penelitian dan Pengembangan Sosial Ekonomi Pertanian, Bogor. 
Laksmana, Rifal. 2015. Analisis Dampak Alih Fungsi Lahan Pertanian Terhadap Kemandirian Pangan Di Kabupaten Subang (Studi Kasus: Desa Belendung, Kecamatan Cibogo). Skripsi. Bogor : Fakultas Ekonomi dan Manajemen, Institut Pertanian Bogor.

Mustopa, Zaenil. 2011. “Analisis Faktor-Faktor Yang Mempengaruhi Alih Fungsi Lahan Pertanian di Kabupaten Demak". Skripsi. Fakultas Ekonomi. Universitas Diponegoro. Semarang.

Nugroho, A. 2005. Strategi Jitu Memilih Metode Statistic Penelitian Dengan SPSS, Andi Yogyakarta, Yogyakarta.

Sugiyono. 2004. Metode Penelitian. Bandung: Alfabeta.

Undang-Undang RI No. 41 Tahun 2009 tentang Perlindungan Lahan Pertanian Pangan Berkelanjutan (PLPPB).

Winoto. 2005. Fakta Alih Fungsi Lahan. Sumatera Utara. Universitas Sumatera Utara.

Yunastiti, Sutomo, \& Nurul Istiqomah, 2015. Analisis Dampak Alih Fungsi Lahan terhadap Tingkat Ketahanan Pangan Rumah Tangga Petani di Karanganyar, Jawa Tengah. Fakultas Ekonomi Universitas Sebelas Maret Surakarta. 